\title{
Brief valuation of Systems, Applications \& Products (SAP) corporation
}

\author{
Yibin Liu, Andrew Gleeson, Ciaran Dowling,Julian Rene Graef
}

\begin{abstract}
SAP is one of the largest players in the commercial software ${ }^{*}$ Correspondence to Author: sector. Following our analysis of SAP's history and capital struc- Yibin Liu ture, it is evident that the company has been able to sustain a stable growth for the past 15 years, whilst also maintaining a stable dividend payout. Barring 2015, SAP's WACC has fallen year on year over the observed period, maximising shareholder How to cite this article:

value and equity prices. Its conservative financing policy, with a Yibin Liu, Andrew Gleeson, Ciaran greater emphasis on equity financing than debt may on the one Dowling,Julian Rene Graef. Brief side foreclose potential growth acceleration, yet also indicates a valuation of Systems, Applications long-sighted managerial conservatism that is focused on long- \& Products (SAP) corporation. term value creation rather than short-term growth. One danger Global journal of Economics and of conservative policies is the potential stalling of further growth. Business Administration, 2018, 3: 7. However, new partnerships such as the newly announced enlargement of SAP's cooperation with Microsoft in the sphere of cloud services point in the right direction towards further growth in a highly saturated sector.

Keywords: valuation of Systems, Applications \& Products eSciPub LLC, Houston, TX USA. Website: http://escipub.com/
\end{abstract}




\section{Profile}

SAP (Systems, Applications \& Products), is a German multinational software corporation founded in 1972 and headquartered in Walldorf. According to Forbes (2017), SAP is the third largest software and programming firm behind Microsoft and Oracle. SAP's software solutions aid global enterprise in facilitating a seamless information flow within, and between, all business functions - accounting and finance, operations and manufacturing, human resources and education, research and development, marketing and sales. It initially was built as a private partnership under the German Civil Code by five IBM engineers. Nowadays, the company has become a flagship brand in the field of enterprise application software, involved in making enterprise software to assist firms and individuals in managing business operations and customer relations in 25 different industries with 60,000 staff across 190 countries.

\subsection{Products}

In the first half of 2017 , SAP gained $€ 1,781$ million in revenue from selling software licenses, and obtained $€ 1,837$ million in revenue from selling cloud services. Compared to the same period in 2016, the revenue from products has increased $8 \%$ and $31 \%$ respectively. Based on the market demand, SAP classify their software and software-related service and selling it by product

combinations:

- ERP (enterprise resource planning) and Digital Core. These simplify the business processes and improve business productivity by cloud ERP solution.

- Procurement and Networks. Which manage procurement processes from suppliers to customers.

- Analytics. To find a company's capacity, to build a proper analysis system and to provide strategies for a dynamic future.

- Cloud and Data Platforms \& Customer Engagement and Commerce. Making it efficient to communicate and strengthen the connection between companies and their clients with timely reaction to market changes.

- IoT and Digital Supply Chain. Creating responsive supply networks and linking useful resources inside and outside the company.

In addition, SAP offers digital products for human resource management and finance.

\subsection{Financial history}

SAP's total revenue has been continuously increasing since the year 2000. In June 2017, the company earned $€ 11,067$ million, an increase of $11 \%$ compared with same period in 2016 (€9,967 million). Profit (after tax) ascended $15 \%$ between $2017(€ 2,006$ million) and 2016 (€1,742 million).

Profitability: From 2000 to 2017, SAP's gross return has been positively stable. Interestingly, the company dramatically had negative return on assets with increasing assets value in many years. The gross margin grew by approx. $€ 10$ million from 2000 to 2016, from $€ 60.54$ million to $€ 70.16$ million.

Revenue by regions: The biggest market for SAP is in APJ (Asia Pacific Japan), where the company earned $€ 1031.462$ million and created $52 \%$ of total revenue in 2000 . Until June 2017 , they explored market in EMEA (Europe,Middle East and Africa), and focused stronger on the Americas market than before. The revenue from EMEA and the Americas market both contributed approx $42 \%$ of totalrevenue.

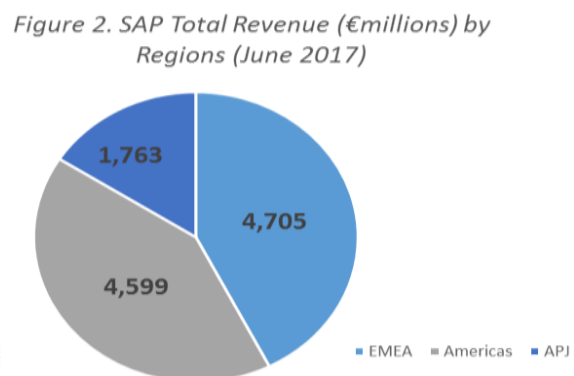

GJEBA: http://escipub.com/global-journal-of-economics-and-business-administration/ 
Financial Liabilities: The total liabilities liabilities ( $€ 19,031$ million) was six times the increased rapidly after 2009, at peak time (2014) liabilities in 2000 (€2,631.2 million).

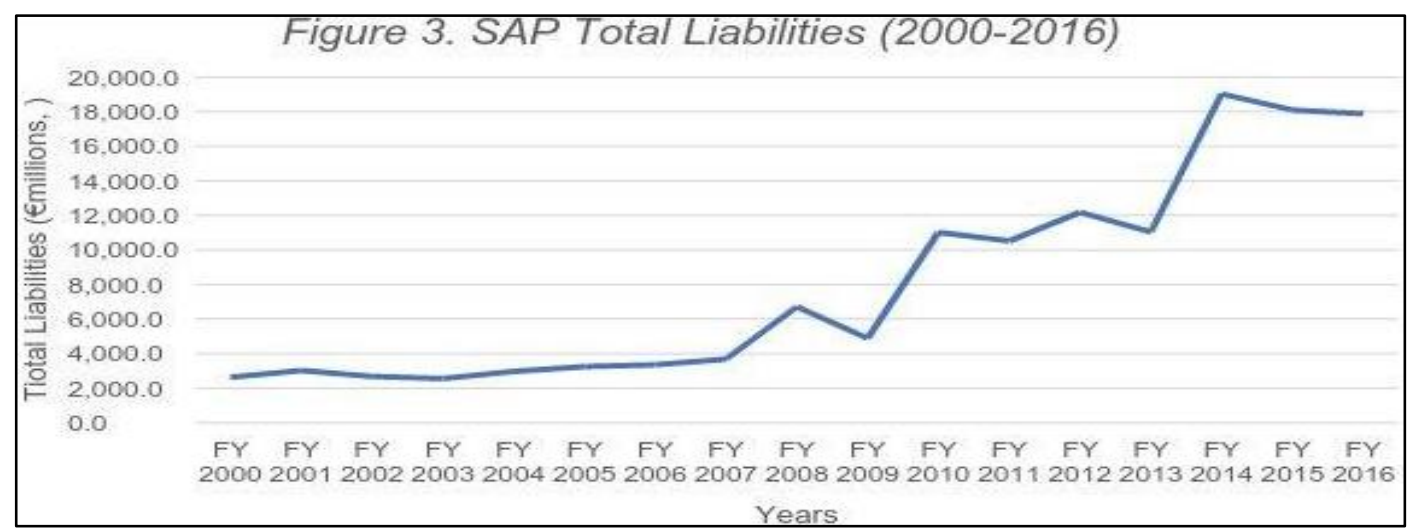

Based on the facts above, SAP retains substantial revenue annually and explores markets around the world.

\section{Capital Structure Analysis}

\subsection{Debt Capitalisation}

In analysing SAP's capital structure there are a number of macroeconomic factors in addition to industry-specific considerations. The organisation appears to have an aversion to

debt relative to other corporations abroadperhaps indicative of SAP's German foundations. At present the company holds an "A2" and "A" long-term credit rating on new debt issuances from both Moody's and Standard \& Poor respectively. It's worth noting here that the company appears to have recently used interest rate swaps to transfer a segment of its outstanding obligations from a fixed rate to a variable plan.

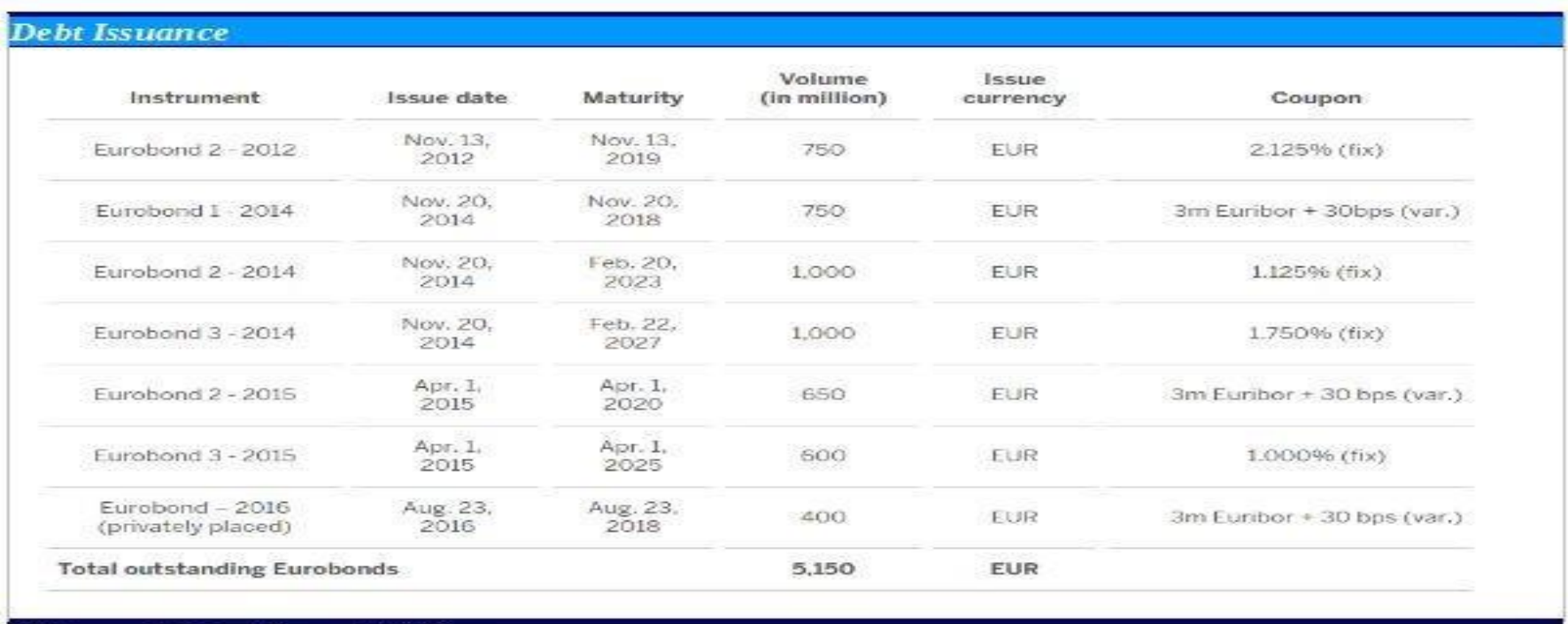

*Figures derived from SAP.de

As displayed below, SAP is not as highly leveraged as many of its peers. Instead, in the recent quarterly report to shareholders, the company reiterated its commitment to conservatism with regards to debt. It is committed to protect the company's high equity ratio, which it maintains is one of its primary financial principles - equity investors cover a greater portion of SAP's assets than debt.
Oracle, by contrast, is an organisation that utilised more deb than SAP to finance its activities. SAP could possibly expand its revenue potential if it was prepared to increase its debt capacity. If earnings from that debt outweighed the interest paid, (stated below) it could deliver value to shareholders.

In terms of leverage, an analysis of market peers demonstrates how Microsoft, along with 
Oracle, have seemed to utilise prolonged low interest rates to increase leverage over the preceding three year period (MSFT leverage ratio stood at $54 \%$ and $\mathrm{ORCL}$ at $52 \%$ as of it has issued more debt since. June and May 2017 respectively). Alternatively,
AP chose to deleverage its balance sheet in that time, moving from $31 \%$ to $16 \%$ (the result of an increased free cash flow of $12 \%$ ), though

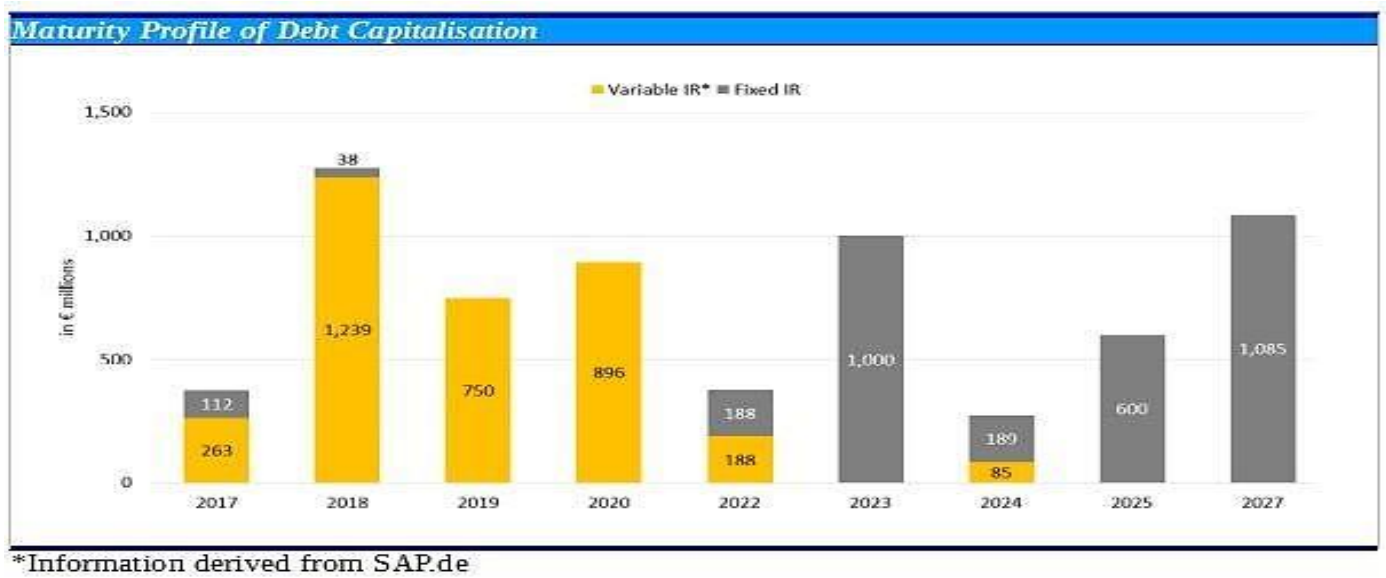

*Information derived from SAP.de

\begin{tabular}{|l|l|l|l|}
\hline \multicolumn{3}{l}{ Debt-to-capital ratios } \\
\hline & 2014 & 2015 & 2016 \\
\hline Microsoft & $20 \%$ & $31 \%$ & $42 \%$ \\
Oracle & $34 \%$ & $46 \%$ & $48 \%$ \\
\hline SAP & $31 \%$ & $23 \%$ & $16 \%$ \\
\hline
\end{tabular}

"INFORMATION DERIVED FROM YCHARTS

\begin{tabular}{|c|c|c|}
\hline \multicolumn{3}{|c|}{ Capital Structure Ratio Analysis (Peer Comparison) } \\
\hline & SAP & ORCL \\
\hline Debt-to-Equity & 0.29 & 0.95 \\
\hline Debt-to-Assets & 18.23 & 42.6 \\
\hline Debt-to-Capital & 0.23 & 0.50 \\
\hline Interest Coverage & $19.27 \%$ & $7.38 \%$ \\
\hline
\end{tabular}

*Information derived from SAP.de \& Oracle.com

From Miller \& Modigliani (1958) and Ross (1977) to more recent academics, the issue of whether an optimal capital structure even exists has been the focus of much empirical research. It is important to note that while a capital mix that leans more aggressively on leverage than SAP's may be in a position to increase shareholder value through a reduction in corporate taxation, managerial efficiency incentives and in its role as an anti-takeover strategy, empirical research on the liberal utilization of debt shows us that firms with such balance sheets are disproportionately impacted through loss of market share over the long term (Opler et al, 1997).

\subsection{Equity Capitalisation}

\begin{tabular}{|c|c|c|c|c|c|}
\hline Major Shareholders (390 & mers) & Share: & & & Value \\
\hline Fisher Asset Mgmt, LLC & & $<6 \mathrm{~m}$ & & & $\mathrm{~S}<700 \mathrm{~m}$ \\
\hline Harding Loevner, LLC & & $<5 \mathrm{~m}$ & & & $\mathrm{~s}<600 \mathrm{~m}$ \\
\hline Harbor International Fund & & $<5 \mathrm{~m}$ & & & $\mathrm{~S}<500 \mathrm{~m}$ \\
\hline Bank of America Corp. & & $<2 \mathrm{~m}$ & & & $\$<250 \mathrm{~m}$ \\
\hline $\begin{array}{l}\text { Equity a } \\
\text { SAP }\end{array}$ & Debt & Equ & wners & 5340 & \\
\hline Type & Mil USD & Type & Mil USD & 3560 & \\
\hline - Equity & 24,370 & - Institutions & 4,852 & 1780 & \\
\hline - Debt & 7,100 & - Mutual Funds & 1,064 & & \\
\hline
\end{tabular}


Liu et al., GJEBA, 2018; 3:7

With a common stock carry value of 1.23 billion, become the basis for our discounted cash flow total shareholder equity rests around 24 billion with 22 billion in retained earnings and 2 billion of additional paid in capital. At 7.6, SAP's weighted-average cost of capital is a significant factor in creating value for shareholders. The WACC that we have calculated below will and dividend policy analysis below. A detailed examination of SAP's shareholder wealth creation is discussed in the following sections.

\subsection{Weighted Average Cost of Capital}

Finding tax rate:

\begin{tabular}{|c|c|c|c|c|c|}
\hline & 2012 & 2013 & 2014 & 2015 & 2016 \\
\hline $\begin{array}{c}\text { Income Before } \\
\text { Tax }\end{array}$ & 3824000 & 4396000 & 4355000 & 3991000 & 4863000 \\
\hline Tax Expenses & 100100 & 1071000 & 1075000 & 935000 & 1229000 \\
\hline Inc. Contin. Ops & 2823000 & 3325000 & 3280000 & 3056000 & 3634000 \\
\hline Effective Tax & 26.2 & 24.4 & 24.6 & 23.4 & 25.3 \\
\hline 5y Avg. Tax Rate = & 24.8 & & & & \\
\hline Risk-Premiun & $.354-0.3$ & $7-$-rf) & & & \\
\hline 0.860 beta & IIved IIOI & an lor $\mathrm{D}$ & & & \\
\hline
\end{tabular}

*Information derived from Bloomberg

So, the Capital Asset Pricing Model (CAPM) is:

$$
E\left(R_{i}\right)=R_{f}+\beta_{i}\left[E\left(R_{M}\right)-R_{f}\right]
$$

$$
8.09 \%=.355+.86(9.0)
$$

\begin{tabular}{|c|c|c|}
\hline \multicolumn{3}{|l|}{ WACC } \\
\hline \multicolumn{2}{|l|}{ Tax Rate } & $24.8 \%$ \\
\hline Rf & 0.36 & \\
\hline $\mathrm{Rm}$ & 9.35 & \\
\hline Beta & 0.86 & \\
\hline \multicolumn{2}{|c|}{ Cost of Equity (Re) } & $8.09 \%(C A P M) R e=0.355+0.860(9)$ \\
\hline Total Debt & 7100 & \\
\hline $\begin{array}{l}\text { Interest Exp. } \\
\text { Income Tax }\end{array}$ & $\begin{array}{l}222 \\
53.3\end{array}$ & \\
\hline \multicolumn{2}{|l|}{ Cost of Debt (Rd) } & 2.38 \\
\hline \multicolumn{2}{|c|}{ Outstanding Shares 1.23} & \\
\hline Market Cap & & 119.35 \\
\hline $\begin{array}{l}\text { BVPS } \\
\text { Book Value }\end{array}$ & $\begin{array}{l}19.84 \\
24.37\end{array}$ & \\
\hline MVA & & 94.98 \\
\hline MVA + Debt & & 102.1 \\
\hline We $(94.98 / 102.1)$ & & $.93026(93 \%)$ \\
\hline Wd $(7.1 / 102.1)$ & & $.0695(7 \%)$ \\
\hline
\end{tabular}

"INFORMATION DERIVED FROM BLOOMBERG

WACC $=7.6=(2.38 \% \times 7.0 \%)+(8.09 \% \times 93.0 \%)=0.1666 \%+7.52 \%$.

\section{Valuation}

\subsection{Relative Valuation}

Our set of eight comparable companies was designed to include SAP's largest and closest competitors, such as Oracle and Microsoft. The companies were selected on a basis of having similar product portfolios and/or being direct

\section{competitors}

of

SAP.

\section{Selection of Multiples}

Price multiples, such as $\mathrm{P} / \mathrm{E}, \mathrm{P} / \mathrm{B}$ and $\mathrm{P} / \mathrm{FCF}$ can be useful valuation tools, as they provide a quick overview of the expected market value relative to a firm's peers. We used forward looking data, as these have been shown to be 
more accurate in predicting value than historical Furthermore, a set of enterprise-value based data (Goedhart, Koller \& Wessels, 2005).

The P/E multiple is widely used as a key valuation indicator, yet has several drawbacks, as earnings reporting is subject to management decisions, and earnings can be zero or even negative. The P/B and P/FCF values are more stable measures than $P / E$, as book value and cash flow are more difficult to manipulate than earnings.

multiples, including EV/EBITDA and EV/Revenue, was selected. Enterprise value includes both debt and equity and can therefore help to mitigate effects of changes in capital structure, which have a strong influence on P/E (Goedhart, Koller \& Wessels,2005). Median values were utilised as a comparison benchmark in the analyses below, as the median tends to be less affected by outliers than the arithmetic mean.

\section{Data Analysis}

\begin{tabular}{|c|c|c|c|c|c|c|}
\hline \multicolumn{7}{|c|}{ Comparable Multiples: Price Multiples } \\
\hline & \multicolumn{2}{|c|}{$\mathrm{P} / \mathrm{E}$} & \multicolumn{2}{|c|}{$\mathrm{P} / \mathrm{B}$} & \multicolumn{2}{|c|}{ P/FCF } \\
\hline & FY1 & $\mathrm{FY} 2$ & FY1 & FY2 & FY1 & FY2 \\
\hline SAP SE & 23.43 & 21.67 & 4.30 & 4.00 & 31.70 & 27.10 \\
\hline CA Inc. & 13.29 & 12.80 & 2.20 & 2.10 & 12.90 & 12.60 \\
\hline Dassault Systemes SA & 34.86 & 31.52 & 5.50 & 5.00 & 39.20 & 32.30 \\
\hline IBM & 11.00 & 10.91 & 6.70 & 6.10 & 11.50 & 11.70 \\
\hline Intuit Inc & 30.86 & 27.56 & 20.90 & 16.90 & 25.20 & 22.90 \\
\hline Microsoft Corp & 24.55 & 22.13 & 6.50 & 5.60 & 19.50 & 17.50 \\
\hline Oracle & 16.62 & 15.40 & 3.40 & 3.10 & 15.00 & 14.30 \\
\hline Sage Group & 23.94 & 21.86 & 7.60 & 6.70 & 23.70 & 22.00 \\
\hline Synopsys Inc & 27.24 & 25.27 & 3.80 & 3.20 & 23.50 & 22.60 \\
\hline Median & 23.94 & 21.86 & 5.50 & 5.00 & 23.50 & 22.00 \\
\hline SAP SE & 23.43 & 21.67 & 4.30 & 4.00 & 31.70 & 27.10 \\
\hline & & & & & & \\
\hline & & & & & & \\
\hline Implied Values & 99.37 & 98.10 & 124.39 & 121.56 & 72.09 & 78.95 \\
\hline SAP Current Share Price & 97.25 & 97.25 & 97.25 & 97.25 & 97.25 & 97.25 \\
\hline Overvalued? & No & No & No & No & Yes & Yes \\
\hline & & & & & & \\
\hline & & & & & & \\
\hline Implied Price & 99.08 & & & & & \\
\hline Implied Upside & $1.88 \%$ & & & & & \\
\hline & & & & & & \\
\hline
\end{tabular}

Data source: Bloomberg

Weighing the implied share prices derived from which is $1.88 \%$ higher than the actual share the $P / E, P / B$ and P/FCF analyses equally, the price.

resulting implied share price is 99.08 EUR,

\begin{tabular}{|c|c|c|c|}
\hline \multicolumn{4}{|c|}{ EV/EBITDA Model } \\
\hline & Low (-1 S.D.) & Base & High (+1 S.D.) \\
\hline EV/EBITDA & 11.44 & 16.58 & 21.72 \\
\hline EV & 79632.99 & 115396.80 & 151160.61 \\
\hline Minority Interest & 0 & 0 & 0 \\
\hline Net Debt & $(7,100)$ & $(7,100)$ & $(7,100)$ \\
\hline Equity Value & 72532.99 & 108296.80 & 144060.61 \\
\hline No. Shares & 1228.50 & 1228.50 & 1228.50 \\
\hline Per Share Value & $\mathbf{5 9 . 0 4}$ & $\mathbf{8 8 . 1 5}$ & $\mathbf{1 1 7 . 2 7}$ \\
\hline Potential Upside & $\mathbf{- 3 9 . 2 9 \%}$ & $\mathbf{- 9 . 3 5 \%}$ & $\mathbf{2 0 . 5 8 \%}$ \\
\hline
\end{tabular}


Data source: Bloomberg

The EV/EBITDA model, on the other hand, further, SAP's ratios across three time periods implies a share price around 88.15 EUR, (last twelve months, forecasted current FY, and implying that SAP's stock is overvalued by $9 \%$ forecasted next FY) were compared to the relative to its peers based on its EBITDA. In median of its peer group:

order to analyse the derived implied prices

\begin{tabular}{|c|c|c|c|c|c|c|c|c|c|c|c|c|c|c|c|}
\hline & \multicolumn{5}{|c|}{ Current Values (LTM) } & \multicolumn{5}{|c|}{ FY1 } & \multicolumn{5}{|c|}{ FY2 } \\
\hline & $\begin{array}{l}\text { Enterprise } \\
\text { Value } \\
\text { (Currency } \\
\text { Adjusted, M) }\end{array}$ & $\begin{array}{l}\text { Current } \\
\text { Shares } \\
\text { Outstanding } \\
\text { (M) }\end{array}$ & BEst EPS & $\begin{array}{l}\text { EV/ } \\
\text { Revenue }\end{array}$ & $\begin{array}{l}\text { EV / } \\
\text { EBITDA }\end{array}$ & $\begin{array}{l}\text { EV/ } \\
\text { Revenue }\end{array}$ & $\begin{array}{l}\text { EV/ } \\
\text { EBITDA }\end{array}$ & $P / E$ & $P / B$ & $\mathrm{P} / \mathrm{FCF}$ & $\begin{array}{l}\text { EV/ } \\
\text { Revenue }\end{array}$ & $\begin{array}{l}\text { EV/ } \\
\text { EBITDA }\end{array}$ & $P / E$ & $P / B$ & $\mathrm{P} / \mathrm{FCF}$ \\
\hline SAPSE & 121548.90 & 1228.50 & 1.50 & 4.94 & 16.58 & 5.20 & 16.60 & 23.43 & 4.30 & 31.70 & 4.90 & 15.52 & 21.67 & 4.00 & 27.10 \\
\hline CAInc. & 11417.61 & 418.54 & 0.51 & 3.38 & 9.75 & 3.20 & 8.90 & 13.29 & 2.20 & 12.90 & 3.20 & 8.51 & 12.80 & 2.10 & 12.60 \\
\hline Dassault Systemes SA & 22017.01 & 260.49 & 0.82 & 6.27 & 22.00 & 6.90 & 19.30 & 34.86 & 5.50 & 39.20 & 6.4 & 17.67 & 31.52 & 5.00 & 32.30 \\
\hline IBM & 146532.41 & 925.79 & 4.33 & 2.15 & 10.21 & 2.20 & 9.10 & 11.00 & 6.70 & 11.50 & 2.20 & 8.71 & 10.91 & 6.10 & 11.70 \\
\hline Intuit Inc & 33063.77 & 255.65 & 0.28 & 7.32 & 23.53 & 6.90 & 18.20 & 30.86 & 20.90 & 25.20 & 6.30 & 16.44 & 27.56 & 16.90 & 22.90 \\
\hline Microsoft Corp & 493982.22 & 7714.59 & 0.73 & 5.55 & 15.10 & 5.50 & 13.90 & 24.55 & 6.50 & 19.50 & 5.1 & 12.34 & 22.13 & 5.60 & 17.50 \\
\hline Oracle & 160384.22 & 4173.05 & 0.58 & 5.13 & 12.25 & 4.80 & 10.20 & 16.62 & 3.40 & 15.00 & 4.70 & 9.64 & 15.40 & 3.10 & 14.30 \\
\hline Sage Group & 10542,49 & 1081.24 & & 4.99 & 17.77 & 5.00 & 16.80 & 23.94 & 7.60 & 23.70 & 4.60 & 15.41 & 21.86 & 6.70 & 22.00 \\
\hline Synopsys Inc & 10540.92 & 150.25 & 0.49 & 4.00 & 17.24 & 4.50 & 16.90 & 27.24 & 3.80 & 23.50 & 4.30 & 16.93 & 25.27 & 3.20 & 22.60 \\
\hline High & 493982.22 & 7714.59 & 4.33 & 7.32 & 23.53 & 6.90 & 19.30 & 34.86 & 20.90 & 39.20 & 6.40 & 17.67 & 31.52 & 16.90 & 32.30 \\
\hline Low & 10540.92 & 150.25 & 0.28 & 2.15 & 9.75 & 2.20 & 8.90 & 11.00 & 2.20 & 11.50 & 2.20 & 8.51 & 10.91 & 2.10 & 11.70 \\
\hline Median & 33063.77 & $925.79^{7}$ & 0.66 & 4.99 & 16.58 & 5.00 & 16.60 & 23.94 & 5.50 & 23.50 & 4.70 & 15.41 & 21.86 & 5.00 & 22.00 \\
\hline Mean & 112225.51 & 1800.90 & 1.16 & 4.86 & 16.05 & 4.91 & 14.43 & 22.87 & 6.77 & 22.47 & 4.63 & 13.46 & 21.01 & 5.86 & 20.33 \\
\hline SAPSE & 121548.90 & 1228.50 & 1.50 & 4.94 & 16.58 & 5.20 & 16.60 & 23.43 & 4.30 & 31.70 & 4.90 & 15.52 & 21.67 & 4.00 & 27.10 \\
\hline SAP SE vs. Median & & & & $-1.00 \%$ & $0.00 \%$ & $4.00 \%$ & $0.00 \%$ & $-2.13 \%$ & $-21.82 \%$ & $34.89 \%$ & $4.26 \%$ & $0.71 \%$ & $-0.87 \%$ & $-20.00 \%$ & $23.18 \%$ \\
\hline SAPSE vs. Mean & & & & $1.67 \%$ & $3.32 \%$ & $5.88 \%$ & $15.01 \%$ & $2.47 \%$ & $-36.45 \%$ & $41.10 \%$ & $5.76 \%$ & $15.28 \%$ & $3.13 \%$ & $-31.69 \%$ & $33.28 \%$ \\
\hline
\end{tabular}

Data source: Bloomberg

SAP's predicted multiples are on average $0.2 \%$ that SAP appears to be fairly valued relative to higher than the median value of its competitors. its closest peers.

Judging from this overview, it can be concluded

3.2 Discounted Cash Flow Analysis Forecasting Free Cash Flows:

\begin{tabular}{|c|c|c|c|c|c|c|}
\hline & 2016 & 2017 & 2018 & 2019 & 2020 & 2021 \\
\hline \multicolumn{7}{|c|}{ Growth \% 4.2} \\
\hline \multicolumn{7}{|c|}{$5 y(Y \circ Y)$ Average } \\
\hline Revenue & 22.06 & 22.99 & 23.96 & 24.97 & 26 & 27.1 \\
\hline EBIT & 5.16 & 5.38 & 5.6 & 5.84 & 6.08 & 6.34 \\
\hline *(1-t) & 3.87 & 4.04 & 4.2 & 4.38 & 4.56 & 4.76 \\
\hline Dep. & 1.27 & 1.36 & 1.45 & 1.56 & 1.66 & 1.78 \\
\hline CAPEX & 1 & 1.04 & 1.08 & 1.13 & 1.18 & 1.23 \\
\hline$\triangle W C$ & 0.42 & 0.44 & 0.46 & 0.48 & 0.51 & 0.54 \\
\hline FCF & 3.72 & 3.92 & 4.11 & 4.33 & 4.53 & 4.77 \\
\hline
\end{tabular}

*INFORMATION DERIVED FROM MARKETWATCH \& YCHARTS ( $\triangle$ WC 5y avg. of 5.1\%; Dep. 5y avg. of $6.9 \%)$

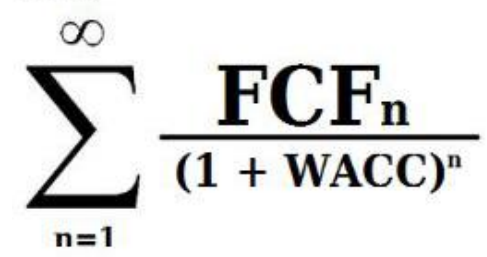

$17.36=\frac{3.92}{(1.076)^{1}}+\frac{4.11}{(1.076)^{2}}+\frac{4.33}{(1.076)^{3}}+\frac{4.53}{(1.076)^{4}}+\frac{4.77}{(1.076)^{5}}$

Finding the Terminal Value and discounting it back:

GJEBA: http://escipub.com/global-journal-of-economics-and-business-administration/ 


\begin{tabular}{l|c|}
\hline Growth Beyond Forecast \% & 4.1 \\
\hline Perpetuity Method: & $\underline{4.77(1+0.04)}$ \\
\hline Terminal Value $=\mathbf{F C F}_{n} \times(\mathbf{1}+g) \div(r-g)$ & $0.076-0.04$ \\
& $\mathrm{t}=137.8$ \\
\hline Present Terminal Value $=\mathbf{9 5 . 5} \Rightarrow$ & $\underline{\mathbf{1 3 7 . 8}}$ \\
\hline
\end{tabular}

\begin{tabular}{l|c}
\hline Equity Value & \\
\hline PV of Free Cash Flows & 17.36 \\
PV of Terminal Value & 95.5 \\
Total Equity Value & $\mathbf{1 1 2 . 8 6}$ \\
Less Debt ( 01/10/17 ) & 17.06 \\
\hline Net Asset Value & $\mathbf{9 5 . 8 6}$ \\
\hline
\end{tabular}

As of $1 / 11 / 17$, shares outstanding rested at $1.23 \mathrm{~B}$ with a price of $\$ 97.1$. We determined a Figure $\approx \$ 77.9(95.86 \mathrm{~B} / 1.23 \mathrm{~B})$, leading us to believe that SAP was overvalued based on the DCF.

\section{Dividend Policy}

\subsection{What was paid out}

Figure A: Dividends Paid Out

\begin{tabular}{|lll|}
\hline Year & Dividend Paid out in $\$$ & Dividend Paid out in Euro \\
\hline 2012 & $\$ 1.11$ & 0.85 \\
\hline 2013 & $\$ 1.37$ & 1 \\
\hline 2014 & $\$ 1.22$ & 1.1 \\
\hline 2015 & $\$ 1.30$ & 1.15 \\
\hline 2016 & $\$ 1.33$ & 1.25 \\
\hline
\end{tabular}

\section{Data Source: Bloomberg}

Above in figure $A$, the breakdown of dividends paid each year compared to number of ordinary shares can be seen in both currencies relative to the exchange rate. SAP as a German company payout dividends in both US Dollar and Euro, with most of their shareholders coming from the United States. SAP has had no preferred dividend/stock for the last 15 years and continues to not have none as of the end of 2016. In the 2016 fiscal year, SAP investors were paid an annual dividend of $\$ 1.31$ per share with a yield of $1.52 \%$. In the most up to date data, dividends payable increased to \$1.48. Considering an Earnings Per Share (EPS) of \$3.65, SAP produced a payout ratio of $40.55 \%$. Investors have been in receivership of a dividend every year since the stock was first floated in 1988. The Company's dividend policy is to return at least $35 \%$ of profit after tax to shareholders every year which we can see above is maintained in the current financial year. Given a recent change in capital allocation requirements in June 2013, management has committed to a repurchase programme that will see $€ 120 \mathrm{~m}$ shares bought back before June 3, 2018. Figure C, highlights peer returns diagrammatically. As we can see from this, Sap gives out a very competitive dividend in relation to its industry leading peers and more than double that of its main competitor Oracle.

Figure B: Dividend Yield \%

\begin{tabular}{lccccc}
\hline & $\mathbf{2 0 1 3}$ & $\mathbf{2 0 1 4}$ & $\mathbf{2 0 1 5}$ & $\mathbf{2 0 1 6}$ & $\mathbf{2 0 1 7}$ \\
\hline Year-end Yield \% & 1.27 & 1.98 & 1.54 & 1.52 & TBD \\
Ex-Dividend Date & MAY 31 & MAY 22 & MAY 18 & MAY 10 & MAY 11 \\
Declaration Date & MAY 7 & APR 8 & JUN 4 & MAY 16 & JUN 4 \\
Record Date & JUN 4 & MAY 21 & MAY 20 & MAY 12 & MAY 15 \\
Payable Date & JUN 12 & MAY 29 & MAY 29 & MAY 20 & MAY 22 \\
\hline Dividend Payable & $\$ 1.11$ & $\$ 1.38$ & $\$ 1.22$ & $\$ 1.31$ & $\$ 1.33$ \\
\hline
\end{tabular}

Figure C: Dividends comparison with other major companies in industry (Data Source: YCharts) GJEBA: http://escipub.com/global-journal-of-economics-and-business-administration/ 
Liu et al., GJEBA, 2018; 3:7

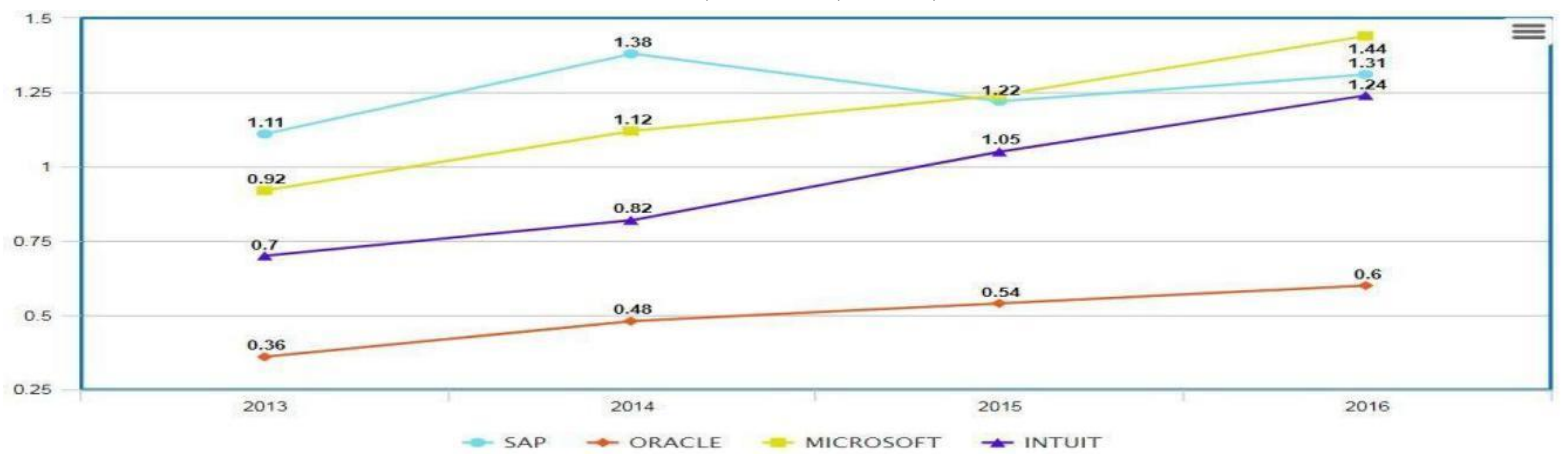

Figure D: Average Yields

IBM
MICROSOFT
ORACLE
INTUIT
SAP
"INFORMATION DERIVED FROM YCHARTS

\subsection{What it could have paid out}

The breakdown of the calculation for the FCFE of SAP can be seen in figure E. Four out of the last five years the value of the FCFE has been greater than the dividends paid (Figure D). This number shows that SAP could have afforded to pay out more in dividends for these four years,
Average $5 y$ Yields \%

2.76
2.55
1.29
1.07
1.53

1.53 as it had left over cash in each of these years. SAP made no repurchases of shares in 2016, but stands to repurchase almost 93,000,000 shares by June 32018 as part of an agreement made at their AGM in 2013.

Figure E: FCFE (Free Cashflow to Equity) for SAP

\begin{tabular}{|l|l|l|l|l|l|}
\hline Years & 2012 & 2013 & 2014 & 2015 & 2016 \\
\hline Cash from Operations & 4629 & 3636 & 3499 & 3832 & 3822 \\
\hline $\begin{array}{l}\text { Capital expenditures/prop added } \\
\text { Disposal of Fixed assets }\end{array}$ & -1001 & -636 & -737 & -566 & -541 \\
\hline Proceeds from repayments of borrowings & -1357 & -2104 & 5441 & -625 & 39 \\
\hline Preferred equity and hybrid capital & 0 & 0 & 0 & 0 & 0 \\
\hline PD01(preferred equity and hybrid capital) & 0 & 0 & 0 & 0 & 0 \\
\hline Preferred Dividends & 0 & 0 & 0 & 0 & 0 \\
\hline FCFE & 2334 & 964 & 8249 & 2696 & 4384 \\
\hline
\end{tabular}

Data Source: Bloomberg

Figure F: FCFE (Free Cashflow to Equity) > Dividends

\begin{tabular}{|l|lll|}
\hline Years & FCFE- From Bloomberg & Dividends & FCFE-Dividends \\
\hline 2012 & 4384 & 1,310 & 3074 \\
\hline 2013 & 2696 & 1,013 & 1683 \\
\hline 2014 & 8249 & 1,194 & 7055 \\
\hline
\end{tabular}




\begin{tabular}{|l|lcc|}
\hline 2015 & 964 & 1316 & -352 \\
\hline 2016 & 2334 & 1,378 & 956 \\
\hline
\end{tabular}

\section{Data Source: Bloomberg}

The positive figures for return on equity and return on capital, as seen in figures $G$ and $H$ respectively, signify that the managers within the company can be trusted with one's cash. As they are constantly making significant returns with what they acquire the firm is showing that it selects its projects very well and continues to do so over time.

Figure G: ROE (Return on Equity) to Cost of Equity

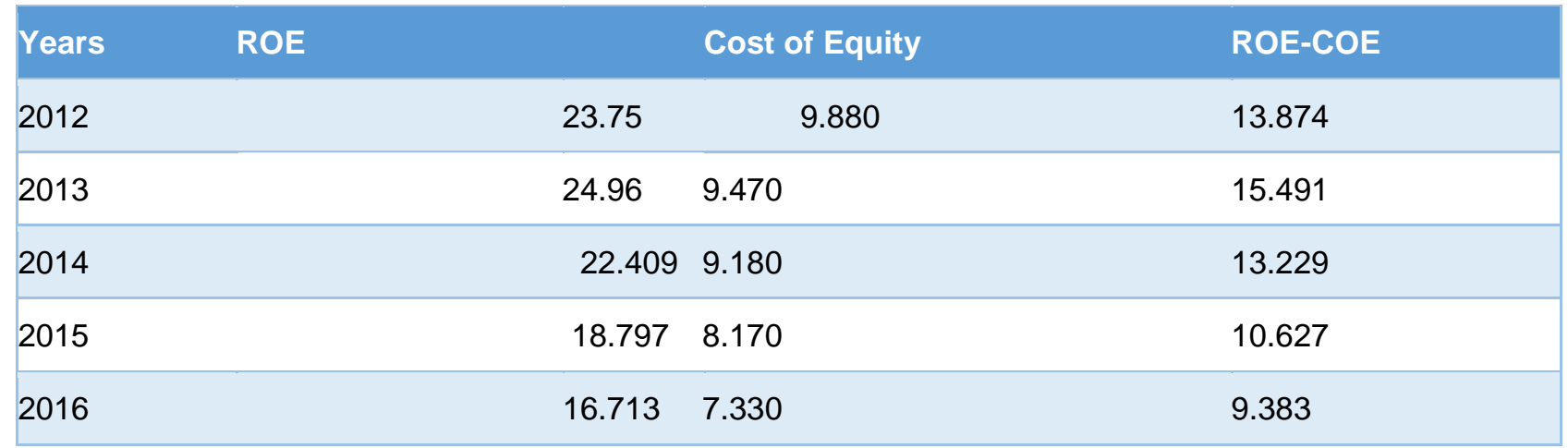

Data Source: Bloomberg

Figure H: ROC (Return on Capital) to WACC (Weighted average cost of Capital)

\begin{tabular}{|lllc|}
\hline Years & ROC (Return on Capital ) & WACC & ROC- WACC \\
\hline 2012 & 16.07 & 9.29 & 6.78 \\
\hline 2013 & 17.34 & 9.02 & 8.32 \\
\hline 2014 & 13.14 & 7.96 & 5.18 \\
\hline 2015 & 10.14 & 7.48 & 2.66 \\
\hline 2016 & 11.31 & 6.79 & 4.52 \\
\hline
\end{tabular}

\section{Data Source: Bloomberg}

Overall Opinion: As SAP continues to give out a reasonable dividend and use the cash that they are holding onto in an efficient manner, shareholders should be happy to let SAP's managers continue as they have done previously.

\section{Conclusion}

SAP is one of the largest players in the commercial software sector. Following our analysis of SAP's history and capital structure, it is evident that the company has been able to sustain a stable growth for the past 15 years, whilst also maintaining a stable dividend payout.
Barring 2015, SAP's WACC has fallen year on year over the observed period, maximising shareholder value and equity prices. Its conservative financing policy, with a greater emphasis on equity financing than debt may on the one side foreclose potential growth acceleration, yet also indicates a long-sighted managerial conservatism that is focused on long-term value creation rather than short-term growth. One danger of conservative policies is the potential stalling of further growth. However, new partnerships such as the newly announced enlargement of SAP's cooperation with Microsoft in the sphere of cloud services point in the right direction towards further growth in a highly saturated sector. 


\section{References}

1 Bloomberg L.P. (2017) . SAP Relative Valuations 14/11/2017. Retrieved November 14, 2017 from Bloomberg Terminal.

2 Forbes. (2017). The World's Biggest Public Companies: 2017 Ranking. Retrieved from https://www.forbes.com/global2000/list/\#header: position industry:Software\%20\%26\%20Program ming

3 Goedhart, M., Koller, T. \& Wessels, D. (2005). The right role for multiples in valuation. Mc Kinsey \& Company Strategy \& Corporate Finance.

\section{Retrieved}

from

https://www.mckinsey.com/business-

functions/strategy-and-corporate-finance/ourinsights/th e-right-role-for-multiples-in-valuation

5 Modigliani, F., \& Miller, M. H. (1958). The cost of capital, corporation finance and the theory of investment. The American economic review, 48(3), 261-297.
6 Ross, S. A. (1977). The determination of financial structure: the incentive-signalling approach. The bell journal of economics, 23-40.

7 N.A. (2017, November 15). SAP Stock report. Retrieved from Morningstar Investment Research Database.

8 Opler, T. C., Saron, M., \& Titman, S. (1997). Designing capital structure to create shareholder value. Journal

9 of Applied Corporate Finance, 10(1), 21-32.

10 SAP. (2016). SAP Annual Report 2016.

11 Retrieved from: https://www.sap.com/docs/download/investors/20 16/sap-2016-annual-report-form-20f.pdf

12 Ycharts (2017). Dividends comparison with other major companies in industry 10/11/17.

13 Retrieved from https://ycharts.com/

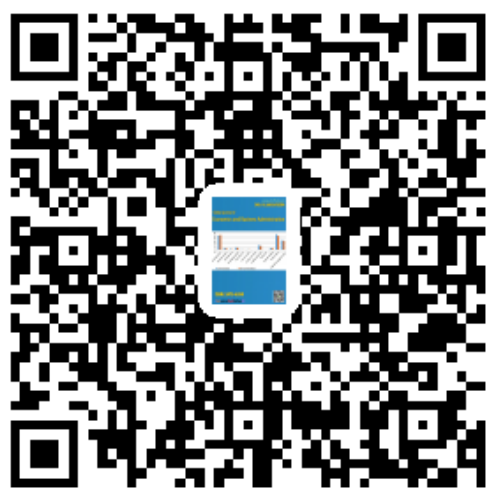


Liu et al., GJEBA, 2018; 3:7

Appendix

EXCEL Calculations

\section{WACC_DCF}

\begin{tabular}{|c|c|c|c|c|c|}
\hline \multicolumn{6}{|l|}{ Tax Rate } \\
\hline & 2012 & 2013 & 2014 & 2015 & 2016 \\
\hline Income Before $t$ & 3824000 & 4396000 & 4355000 & 3991000 & 4863000 \\
\hline Tax Exp. & 100100 & 1071000 & 1075000 & 935000 & 1229000 \\
\hline Income Contin. Ops & 2823000 & 3325000 & 3280000 & 3056000 & 3634000 \\
\hline Effective tax & 26.2 & 24.4 & 24.6 & 23.4 & 25.3 \\
\hline 5y Avg. Tax Rate $=$ & 24.8 & & & & \\
\hline Cost of Equity (Re) & \multicolumn{5}{|c|}{ Cost of Debt (Rd) } \\
\hline $\mathrm{Rm}$ & \multicolumn{2}{|l|}{9.354} & \multicolumn{3}{|c|}{ Total Debt 7100} \\
\hline Rf & \multicolumn{2}{|l|}{0.355} & \multicolumn{3}{|c|}{ Interest Exp222 } \\
\hline Premium & \multicolumn{2}{|l|}{8.999} & \multicolumn{3}{|c|}{ Income Tax 53.3} \\
\hline beta & \multicolumn{5}{|l|}{0.86} \\
\hline $\mathrm{CAPM}=$ & 8.09 & & $\mathrm{Rd}=$ & 2.38 & \\
\hline \multicolumn{6}{|l|}{ WACC } \\
\hline Share Price & 97.1 & & & & \\
\hline Outstanding Shares & 1.23 & & & & \\
\hline Market Cap & & 119.35 & & & \\
\hline BVPS & 19.84 & & & & \\
\hline Book Value & 24.37 & & & & \\
\hline MVA & & 94.98 & & & \\
\hline MVA + Debt & & 102.1 & & & \\
\hline We & & 0.93026 & & & \\
\hline Wd & & 0.0695 & & & \\
\hline WACC $=$ & & 7.6 & & & \\
\hline
\end{tabular}

\begin{tabular}{|c|c|c|c|c|c|c|}
\hline \multicolumn{7}{|l|}{ DCF } \\
\hline & 2016 & 2017 & 2018 & 2019 & 2020 & 2021 \\
\hline Revenue & 22.06 & 22.99 & 23.96 & 24.97 & 26 & 27.1 \\
\hline EBIT & 5.16 & 5.38 & 5.6 & 5.84 & 6.08 & 6.34 \\
\hline$(1-t)$ & 3.87 & 4.04 & 4.2 & 4.38 & 4.56 & 4.76 \\
\hline Dep. & 1.27 & 1.36 & 1.45 & 1.56 & 1.66 & 1.78 \\
\hline CAPEX & 1 & 1.04 & 1.08 & 1.13 & 1.18 & 1.23 \\
\hline WC (ch.) & 0.42 & 0.44 & 0.46 & 0.48 & 0.51 & 0.54 \\
\hline $\mathrm{FCF}$ & 3.72 & 3.92 & 4.11 & 4.33 & 4.53 & 4.77 \\
\hline FCF PV & & 3.64 & 3.55 & 3.47 & 3.38 & 3.31 \\
\hline Sum of PV FCF = & 17.36 & & & & & \\
\hline \multicolumn{7}{|l|}{ Terminal Value } \\
\hline Year 5 & 4.77 & & & & & \\
\hline Growth Rate & 0.04 & & & & & \\
\hline WACC & 0.076 & & & & & \\
\hline Terminal Value $=$ & 137.8 & & & & & \\
\hline Terminal PV = & 95.5 & & & & & \\
\hline Value & 112.86 & & & & & \\
\hline Debt & 17.06 & & & & & \\
\hline $\mathrm{NAV}=$ & 95.86 & & & & & \\
\hline Per Share Value & 77.9 & & & & & \\
\hline Current Share Price & 97.1 & $>$ & 77.9 & Over & & \\
\hline
\end{tabular}




\begin{tabular}{|c|c|c|c|c|c|c|c|c|c|c|c|c|c|c|c|c|c|c|}
\hline \multirow[b]{3}{*}{ SAP SE } & \multicolumn{5}{|c|}{ Current Values (LTM) } & \multicolumn{5}{|c|}{ FY1 } & \multicolumn{5}{|c|}{$\mathrm{F} / 2$} & \multicolumn{3}{|c|}{ Blended Forward } \\
\hline & $\begin{array}{l}\text { Enterprise } \\
\text { Value } \\
\text { (Currency } \\
\text { Adjusted, M) }\end{array}$ & $\begin{array}{l}\text { Current Shares } \\
\text { Outstanding } \\
\text { (M) }\end{array}$ & BEst EPS & $\begin{array}{l}\text { EV/ } \\
\text { Revenue }\end{array}$ & $\begin{array}{l}\text { EV/ } \\
\text { EBTDA }\end{array}$ & $\begin{array}{l}\text { EV/ } \\
\text { Revenue }\end{array}$ & $\begin{array}{l}\text { EV/ } \\
\text { EBITDA }\end{array}$ & $P / E$ & $P / B$ & $\mathrm{P} / \mathrm{FCF}$ & $\begin{array}{l}\text { EV/ } \\
\text { Revenue }\end{array}$ & $\begin{array}{l}\text { EV/ } \\
\text { EBITDA }\end{array}$ & $P / E$ & $P / B$ & $\mathrm{P} / \mathrm{FCF}$ & $\begin{array}{l}\text { EV / } \\
\text { Revenue }\end{array}$ & EV/EBITDA BF & $P / F C F$ \\
\hline & 121548.90 & 1228.50 & 1.50 & 4.94 & 16.58 & 5.20 & 16.60 & 23.43 & 4.30 & 31.70 & 4.90 & 15.52 & 21.67 & 4.00 & 27.10 & 4.90 & 15.60 & 27.50 \\
\hline CAlnc. & 11417.61 & 418.54 & 0.51 & 3.38 & 9.75 & 3.20 & 8.90 & 13.29 & 2.20 & 12.90 & 3.20 & 8.51 & 12.80 & 2.10 & 12.60 & 3.20 & 8.60 & 12.70 \\
\hline Dassault Systemes SA & 22017.01 & 260.49 & 0.82 & 6.27 & 22.00 & 6.90 & 19.30 & 34.86 & 5.50 & 39.20 & 6.4 & 17.67 & 31.52 & 5.00 & 32.30 & 6.4 & 17.8 & 32.90 \\
\hline IBM & 146532.41 & 925.79 & 4.33 & 2.15 & 10.21 & 2.20 & 9.10 & 11.00 & 6.70 & 11.50 & 2.20 & 8.71 & 10.91 & 6.10 & 11.70 & 2.20 & 8.70 & 11.70 \\
\hline Intuit Inc & 33063.77 & 255.65 & 0.28 & 7.32 & 23.53 & 6.90 & 18.20 & 30.86 & 20.90 & 25.20 & 6.30 & 16.44 & 27.56 & 16.90 & 22.90 & 6.70 & 17.60 & 24.40 \\
\hline MicrosoftCorp & 493982.22 & 7714.59 & 0.73 & 5.55 & 15.10 & 5.50 & 13.90 & 24.55 & 6.50 & 19.50 & 5.1 & 12.34 & 22.13 & 5.60 & 17.50 & 5.4 & 13.20 & 18.70 \\
\hline Oracle & 160384.22 & 4173.05 & 0.58 & 5.13 & 12.25 & 4.80 & 10.20 & 16.62 & 3.40 & 15.00 & 4.70 & 9.64 & 15.40 & 3.10 & 14.30 & 4.70 & 9.90 & 14.60 \\
\hline Sage Group & 10542.49 & 1081.24 & & 4.99 & 17.77 & 5.00 & 16.80 & 23.94 & 7.60 & 23.70 & 4.60 & 15.41 & 21.86 & 6.70 & 22.00 & 4.90 & 16.60 & 13.40 \\
\hline Synopsys Inc & 10540.92 & 150.25 & 0.49 & 4.00 & 17.24 & 4.50 & 16.90 & 27.24 & 3.80 & 23.50 & 4.30 & 16.93 & 25.27 & 3.20 & 22.60 & 4.50 & 16.20 & 22.60 \\
\hline High & 493982.22 & 7714.59 & 4.33 & 7.32 & 23.53 & 6.90 & 19.30 & 34.86 & 20.90 & 39.20 & 6.40 & 17.67 & 31.52 & 16.90 & 32.30 & 6.70 & 17.80 & 32.90 \\
\hline Low & 10540.92 & 150.25 & 0.28 & 2.15 & 9.75 & 2.20 & 8.90 & 11.00 & 2.20 & 11.50 & 2.20 & 8.51 & 10.91 & 2.10 & 11.70 & 2.20 & 8.60 & 11.70 \\
\hline Median & 33063.77 & 925.79 & 0.66 & 4.99 & 16.58 & 5.00 & 16.60 & 23.94 & 5.50 & 23.50 & 4.70 & 15.41 & 21.86 & 5.00 & 22.00 & 4.90 & 15.60 & 18.70 \\
\hline Mean & 112225.51 & 1800.90 & 1.16 & 4.86 & 16.05 & 4.91 & 14.43 & 22.87 & 6.77 & 22.47 & 4.63 & 13.46 & 21.01 & 5.86 & 20.33 & 4.77 & 13.80 & 19.83 \\
\hline SAP SE & 121548.90 & 1228.50 & 1.50 & 4.94 & 16.58 & 5.20 & 16.60 & 23.43 & 4.30 & 31.70 & 4.90 & 15.52 & 21.67 & 4.00 & 27.10 & 4.90 & 15.60 & 27.50 \\
\hline SAP SE us. Median & & & & $-1.00 \%$ & $0.00 \%$ & $4.00 \%$ & $0.00 \%$ & $-2.13 \%$ & $-21.82 \%$ & $34.89 \%$ & $4.26 \%$ & $0.71 \%$ & $-0.87 \%$ & $-20.00 \%$ & $23.18 \%$ & $0.00 \%$ & $0.00 \%$ & $47.06 \%$ \\
\hline SAP SE vs. Mean & & & & $1.67 \%$ & $3.32 \%$ & $5.88 \%$ & $15.01 \%$ & $2.47 \%$ & $6-36.45 \%$ & $41.10 \%$ & $5.76 \%$ & $6 \quad 15.28 \%$ & $3.13 \%$ & $=31.69 \%$ & $33.28 \%$ & $2.80 \%$ & $13.04 \%$ & $38.66 \%$ \\
\hline
\end{tabular}

\begin{tabular}{|c|c|c|c|c|c|c|c|}
\hline \multicolumn{8}{|c|}{ Comparable Multiples: Price Multiples } \\
\hline & \multicolumn{3}{|c|}{$\mathrm{P} / \mathrm{E}$} & \multicolumn{2}{|c|}{$\mathrm{P} / \mathrm{B}$} & \multicolumn{2}{|c|}{$\mathrm{P} / \mathrm{FCF}$} \\
\hline & FY1 & & & FY1 & & FY1 & \\
\hline SAP SE & & 23.43 & 21.67 & 4.30 & 4.00 & 31.70 & 27.10 \\
\hline CA Inc. & & 13.29 & 12.80 & 2.20 & 2.10 & 12.90 & 12.60 \\
\hline Dassault Systemes SA & & 34.86 & 31.52 & 5.50 & 5.00 & 39.20 & 32.30 \\
\hline IBM & & 11.00 & 10.91 & 6.70 & 6.10 & 11.50 & 11.70 \\
\hline Intuit Inc & & 30.86 & 27.56 & 20.90 & 16.90 & 25.20 & 22.90 \\
\hline Microsoft Corp & & 24.55 & 22.13 & 6.50 & 5.60 & 19.50 & 17.50 \\
\hline Oracle & & 16.62 & 15.40 & 3.40 & 3.10 & 15.00 & 14.30 \\
\hline Sage Group & & 23.94 & 21.86 & 7.60 & 6.70 & 23.70 & 22.00 \\
\hline Synopsys Inc & & 27.24 & 25.27 & 3.80 & 3.20 & 23.50 & 22.60 \\
\hline Median & & 23.94 & 21.86 & 5.50 & 5.00 & 23.50 & 22.00 \\
\hline SAP SE & & 23.43 & 21.67 & 4.30 & 4.00 & 31.70 & 27.10 \\
\hline Implied Values & & 99.37 & 98.10 & 124.39 & 121.56 & 72.09 & 78.95 \\
\hline SAP Current Share Price & & 97.25 & 97.25 & 97.25 & 97.25 & 97.25 & 97.25 \\
\hline Overvalued? & & No & No & No & No & Yes & Yes \\
\hline Implied Price & & 99.08 & & & & & \\
\hline Implied Upside & & $1.88 \%$ & & & & & \\
\hline
\end{tabular}




\begin{tabular}{|c|c|c|c|c|c|}
\hline \multicolumn{4}{|c|}{ EV/EBITDA Model } & & \\
\hline & Low (-1 S.D.) & Base & High (+1 S.D.) & & \\
\hline EV/EBITDA & 11.44 & 16.58 & 21.72 & & \\
\hline EV & 79632.99 & 115396.80 & 151160.61 & & \\
\hline Minority Interest & 0 & 0 & 0 & & \\
\hline Net Debt & $(7,100)$ & $(7,100)$ & $(7,100)$ & & \\
\hline Equity Value & 72532.99 & 108296.80 & 144060.61 & & \\
\hline No. Shares & 1228.50 & 1228.50 & 1228.50 & Company: & SAP \\
\hline Per Share Value & 59.04 & 88.15 & 117.27 & Share Price: & 97.25 \\
\hline Potential Upside & $-39.29 \%$ & $-9.35 \%$ & $20.58 \%$ & EBITDA & 6,960 \\
\hline
\end{tabular}

\begin{tabular}{|lr|}
\hline Company Name & EV/EBITDA \\
\hline SAP SE & 16.58 \\
CA Inc. & 9.75 \\
Dassault Systemes SA & 22.00 \\
IBM & 10.21 \\
Intuit Inc & 23.53 \\
Microsoft Corp & 15.10 \\
Oracle & 12.25 \\
Sage Group & 17.77 \\
Synopsys Inc & 17.24 \\
\hline Median & $\mathbf{1 6 . 1 7}$ \\
\hline Standard Deviation & $\mathbf{5 . 1 4}$ \\
\hline
\end{tabular}

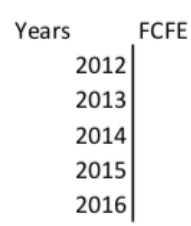

In Millions of EUR except Per Share

\begin{tabular}{r|r|r|} 
& \\
$4,384.0$ & Dividends paid & cost of equity \\
$2,696.0$ & $-1,310.0$ & 83.732 \\
$8,249.0$ & $-1,013.0$ & -22.670 \\
964.0 & $-1,194.0$ & 17.869 \\
$2,334.0$ & $-1,316.0$ & 10.219 \\
& $-1,378.0$ & 4.713
\end{tabular}

last price

\begin{tabular}{rr|r} 
Years cost of equity & & ROE \\
2012 & 9.000 \\
2013 & -22.670 & 23.75 \\
2014 & 17.869 & 24.96 \\
2015 & 10.219 & 22.409 \\
2016 & 4.713 & 18.797 \\
& & 16.713
\end{tabular}

\begin{tabular}{|c|c|c|c|}
\hline Years & ROE & cost of equity & ROE-COE \\
\hline 2012 & 23.75 & 9.880 & 13.874 \\
\hline 2013 & 24.96 & 9.470 & 15.491 \\
\hline 2014 & 22.409 & 9.180 & 13.229 \\
\hline 2015 & 18.797 & 8.170 & 10.627 \\
\hline 2016 & 16.713 & 7.330 & 9.383 \\
\hline
\end{tabular}

\begin{tabular}{|cccc|}
\hline Years & ROC ( Return on Capital) & WACC & ROC- WACC \\
\hline 2012 & 16.07 & 9.29 & 6.78 \\
\hline 2013 & 17.34 & 9.02 & 8.32 \\
\hline 2014 & 13.14 & 7.96 & 5.18 \\
\hline 2015 & 10.14 & 7.48 & 2.66 \\
\hline 2016 & 11.31 & 6.79 & 4.52 \\
\hline
\end{tabular}

\begin{tabular}{ccc} 
Years & \multicolumn{2}{c}{ ROC (Rate-of-Change ) } \\
2012 & 9.29 & 48.568 \\
2013 & 9.02 & 2.669 \\
2014 & 7.96 & -6.500 \\
2015 & 7.48 & 25.953 \\
2016 & 6.79 & 12.851
\end{tabular}


Liu et al., GJEBA, 2018; 3:7

\begin{tabular}{|c|c|c|c|}
\hline Year & Dividend Paid out in $\$$ & Dividend Paid out in Euro & \\
\hline & $012 \$ 1.11$ & & 0.85 \\
\hline & $013 \$ 1.37$ & & \\
\hline & $014 \$ 1.22$ & & 1. \\
\hline & $015 \$ 1.30$ & & 1.15 \\
\hline & $016 \$ 1.33$ & & 125 \\
\hline
\end{tabular}

Dividend Payout ratio
\[ \begin{array}{r}45.74 \\ 35.9 \\ 40.09 \\ 44.97 \\ 4109\end{array} \]

Equity Repurchase

$\begin{array}{ll}\text { EUrovalue } & \text { Ordinary shares } \\ 2012 & 1,310 \\ 2013 & 1,013 \\ 2014 & 1,194 \\ 2015 & 1316 \\ 2016 & 1,378\end{array}$

Formula of free cash flow to equity

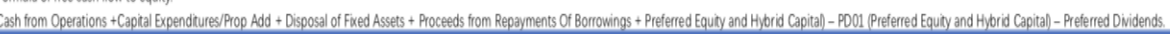

\begin{tabular}{|c|c|c|c|c|c|c|c|}
\hline FCFE & & & ddd & 15 & 195 preferred equity and Hybrid Capital & PDOILprefereded equity and Hybrid Capital) & preferred dividends \\
\hline 2012 & 4384 & 3822 & .541 & 39 & 1064 & 0 & 0 \\
\hline 2013 & 2696 & 3832 & .566 & 55 & .625 & 0 & 0 \\
\hline 2014 & 8249 & 3499 & .737 & 46 & 5441 & 0 & 0 \\
\hline 2015 & 964 & 3636 & .636 & 68 & -2104 & 0 & 0 \\
\hline 2016 & 2334 & 4629 & -1001 & 63 & -1357 & 0 & 0 \\
\hline
\end{tabular}

Figure Relative Data of FCFE formula

Source: Bbomberg
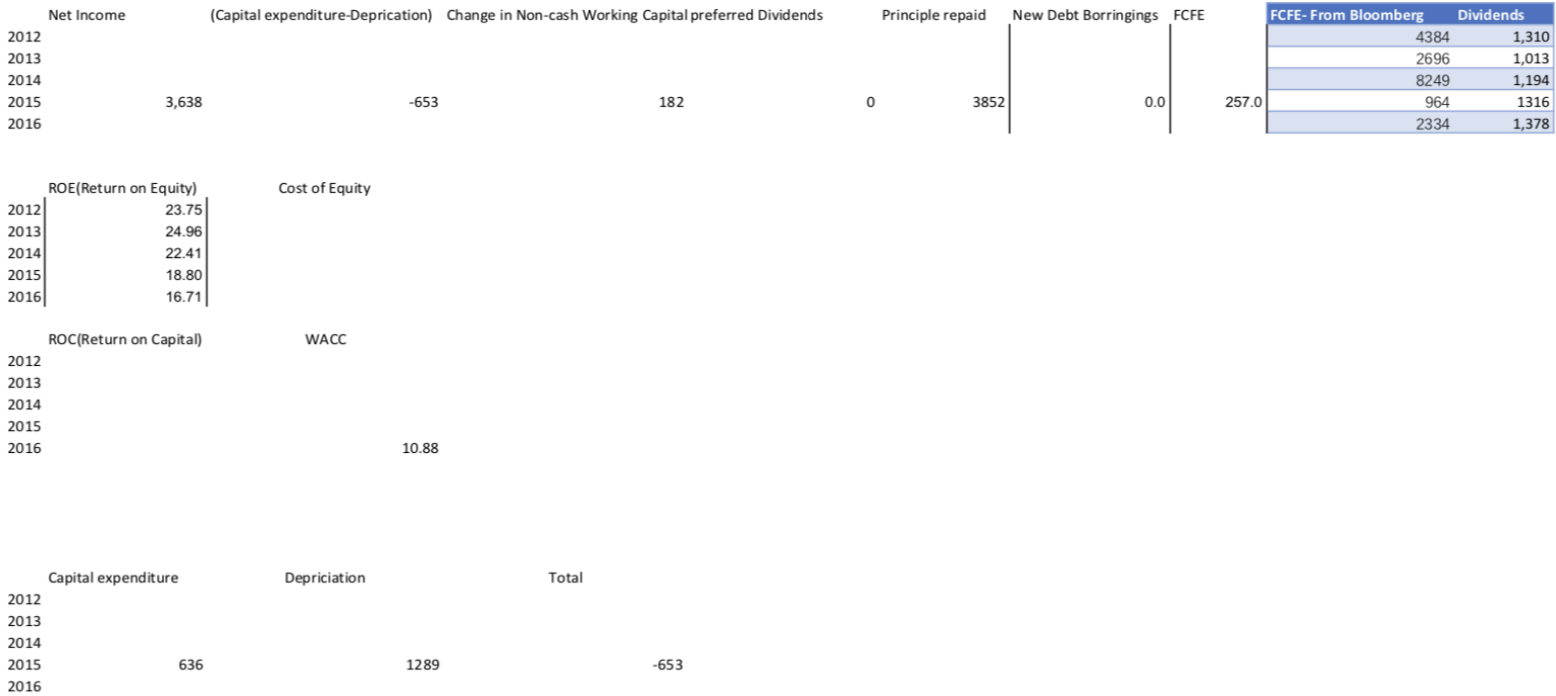
Liu et al., GJEBA, 2018; 3:7

FCFE Workings

Net Income

2012

2013

2014

2015

2016

4,629

Depriciation and Amortisation

1268

Capital Expenditures

1,001

Change in Non-cash Working Capital

Preferred Dividend

Principle Repaid

New Debt Issued

\begin{tabular}{|c|c|c|c|c|c|c|c|c|}
\hline Years & $\begin{array}{l}\text { cash from } \\
\text { operations }\end{array}$ & $\begin{array}{c}\text { capital } \\
\text { expenditures } \\
\text { /Prop Add }\end{array}$ & $\begin{array}{l}\text { disposal of } \\
\text { fixed } \\
\text { assets }\end{array}$ & $\begin{array}{l}\text { proceeds from } \\
\text { repayments of } \\
\text { borrowings }\end{array}$ & $\begin{array}{c}\text { preferred } \\
\text { equity and } \\
\text { Hybrid Capital }\end{array}$ & $\begin{array}{l}\text { PD01(preferre } \\
\text { d equity and } \\
\text { Hybrid } \\
\text { Capital) }\end{array}$ & $\begin{array}{l}\text { preferred } \\
\text { dividends }\end{array}$ & FCFE \\
\hline 2012 & 3822 & -541 & 39 & 1064 & 0 & 0 & 0 & 4384 \\
\hline 2013 & 3832 & -566 & 55 & -625 & 0 & 0 & 0 & 2696 \\
\hline 2014 & 3499 & -737 & 46 & 5441 & 0 & 0 & 0 & 8249 \\
\hline 2015 & 3636 & -636 & 68 & -2104 & 0 & 0 & 0 & 964 \\
\hline 2016 & 4629 & -1001 & 63 & -1357 & 0 & 0 & 0 & 2334 \\
\hline
\end{tabular}

\begin{tabular}{|c|c|c|c|c|c|c|c|}
\hline Years & & cash from operations capital expenditures/Prop Add & disposal of fixed assets & proceeds from repayments of borrowings & PD01(preferred equity and Hybrid Capital) & & ferred dividends \\
\hline 2012 & 4384 & 3822 & .541 & 1064 & 0 & 0 & 0 \\
\hline 2013 & 2696 & 3832 & .566 & .625 & 0 & 0 & 0 \\
\hline 2014 & 8249 & 3499 & .737 & 5441 & 0 & 0 & 0 \\
\hline 2015 & 964 & 3636 & .636 & .2104 & 0 & 0 & 0 \\
\hline 2016 & 2334 & 4629 & .1001 & . 1357 & 0 & 0 & 0 \\
\hline
\end{tabular}

